\title{
EGU2020-18441
}

https://doi.org/10.5194/egusphere-egu2020-18441

EGU General Assembly 2020

(c) Author(s) 2021. This work is distributed under

the Creative Commons Attribution 4.0 License.

\section{The role of Southern Africa as a dust precursor to East Antarctica}

\author{
Stefania Gili ${ }^{1}$, Aubry Vanderstraeten ${ }^{1}$, Mathieu Cazaunau ${ }^{2}$, Amelie Chaput ${ }^{3}$, Jean-Francois \\ Doussin $^{2}$, Claudia Di Biagio ${ }^{2}$, Paola Formenti ${ }^{2}$, James Stephen King ${ }^{3}$, Alexander Magnold ${ }^{4}$, Nadine \\ Mattielli ${ }^{1}$, Edouard Pangui ${ }^{2}$, Preben Van Overmeiren ${ }^{5}$, and Christophe Walgraeve ${ }^{5}$ \\ ${ }^{1}$ University Libre de Bruxelles, G-Time Laboratorie, Département des Géosciences, Environnement et Société, Belgium \\ (stefania.gili@ulb.ac.be) \\ 2 LISA, UMR CNRS 7583, Université Paris-Est-Créteil, Université de Paris, Institut Pierre Simon Laplace (IPSL), Créteil, France. \\ ${ }^{3}$ Laboratoire d'Erosion Eolienne, Dpt. de geographie, Universite de Montreal, Canada. \\ ${ }^{4}$ Royal Meteorological Institute of Belgium (RMI), Ukkel, Belgium \\ ${ }^{5}$ Ghent University, Faculty of Bioscience Engineering, EnVOC group, Belgium.
}

Identifying the provenance of mineral dust depositions in Antarctica is crucial to reconstruct Southern Hemisphere (SH) atmospheric circulation, validate numerical models, evaluate their contribution as micronutrients in the Southern Ocean and assess their control on the climate changes. For the last few decades, it has been demonstrated Southern South America (SSA) is the main precursor of dust reaching Antarctica during both ice ages and interglacial periods (e.g. Gili et al., 2017, 2016). However, the origin of modern dust depositions on the Antarctic continent is still poorly constrained. Back in the nineties, together with SSA, Australia, New Zealand, and Southern Africa were firstly identified as dust contributors to East Antarctica (EA) (e.g. Delmonte et al., 2004a). Since then, only SSA and Australian dust sources benefited from detailed studies. While some works identified the Makgadikgadi and Etosha Pans as southern Africa's major mineral dust sources in the $\mathrm{SH}$, it was not until recently the Namib Desert coastal areas were described as another important regional dust sources. Within the Namib Desert and along the coast, the Kuiseb $(\mathrm{K})$, Omaruru $(\mathrm{O})$ and Huab $(\mathrm{H})$ dry riverbeds are the three main areas identified as the dustiest ones with the higher frequency of dust emission events (Von Holdt et al., 2017). Here we use Sr, $\mathrm{Nd}$ and $\mathrm{Pb}$ isotopes (measured on HR-MC-ICP-MS) to characterize and evaluate the influence of this region in Southern Africa as a dust source to EA. Samples collected in $\mathrm{K}, \mathrm{O}$ and $\mathrm{H}$ desertic areas were analyzed together with snow samples collected along a $\sim 250 \mathrm{~km} \mathrm{~N}$-S transect (defined from the coast to inland) at seven different sampling sites in the surroundings of Dronning Maud Land, EA. In addition, using the bulk of the Huab region, dust aerosols were generated into an atmospheric simulation chamber (CESAM) to reproduce, mechanically the saltation and sandblasting processes responsible for the release of mineral dust in natural conditions. Our isotopic results show Namibia's coast emerged as another possible source end-member, together with some regions in SSA, that supply dust to EA during warmer periods.

References:

Delmonte, B., Basile-Doelsch, I., Petit, J.R., Maggi, V., Revel-Rolland, M., Michard, A., Jagoutz, E., 
Grousset, F., 2004. Comparing the EPICA and Vostok dust records during the last 220,000 years: stratigraphical correlation and provenance in glacial periods. Earth-Sci. Rev. 66, 63-87.

Gili, S., Gaiero, D.M., Goldstein, S.L., Chemale, F. Jr., Koester, E., Jweda, J., Vallelonga, P., Kaplan, M.R., 2016. Provenance of dust to Antarctica: a lead isotopic perspective. Geophys. Res. Lett. 43. http://dx.doi.org/10.1002/2016GL068244.

Gili, S., D.M. Gaiero, S.L. Goldstein, F. Chemale, J. Jweda, M.R. Kaplan, R.A. Becchio, and E. Koester (2017). Glacial/interglacial changes of Southern Hemisphere wind circulation from the geochemistry of South American dust. Earth Planet. Sci. Lett., 469, 98-109, doi: 10.1016/j.epsl.2017.04.007.

Von Holdt, JR., Eckardt FD., and Wiggs GFS., 2017. Landsat identifies aeolian dust emission dynamics at the landform scale. Remote Sensing of Environment 198., 229-243. 